\title{
O BAIÃO DE PRINCESAS DA CASA FANTI-ASHANTI: Um estudo cromático no ensino de Arte à luz da Lei N 10.639/03
}

\author{
Antonio de Assis Cruz Nunes ${ }^{1}$ \\ Luis Félix de Barros Vieira Rocha² \\ Lucileide Martins Borges Ferreira ${ }^{3}$
}

\section{RESUMO}

O presente artigo trata sobre a cromática no ritual afro-maranhense "Baião de Princesas", na Casa Fanti-Ashanti na cidade de São Luís. O estudo parte da Lei de $N^{\circ}$ 10.639/03 que torna obrigatório o ensino da História e Cultura Afro-Brasileira e Africana no currículo das instituições escolares. Na perspectiva do ensino de Arte, especificamente na linguagem de Artes Visuais, foi descrita a simbologia das cores usadas nas vestimentas das vodunsis e das ornamentações do salão, o qual, acontece o ritual religioso afro-maranhense. Para o desenvolvimento textual, foram utilizados aportes teóricos relacionados a cores, religiosidades afro-brasileiras e ensino de Arte. A investigação conclui que o ensino de Arte pode ser um componente curricular para a compreensão e a difusão da religiosidade de matrizes africana e afro-brasileira nos espaços escolares.

Palavras-chave: Currículo. Estudo Cromático. Baião de Princesa.

THE PRINCESS HOUSE OF THE FANTI-ASHANTI HOUSE: a chromatic study in the teaching of Art in light of Law $N^{\circ} 10.639$ / 03

\begin{abstract}
The present article deals with chromatic art in the Afro-Maranhese ritual Baião de Princesas at Fanti-Ashanti House in the city of São Luís. The study begins with an examination of Law No. 10.639 / 03, which makes it compulsory the inclusion of AfroBrazilian and African history and culture in the school curriculum. In the perspective of the teaching of Art, specifically in the Visual Arts language, it was described the symbolism of the colors used in the vestments of the vodunsis and the decorations of the hall where the Afro-Maranhense religious ritual takes place. For textual

1 Doutor em Educação (UNESP). Mestre em Educação (UFMA); Professor Adjunto (UFMA). Orcid iD: http://orcid.org/0000-0002-5939-7706.E-mail: antonio.assis@ufma.br

2 Mestre em Educação: Gestão de Ensino da Educação Básica (UFMA); Especialista em Política de Igualdade Racial no Ambiente Escolar (UFMA). Orcid iD: http://orcid.org/00000002-9309-3175. E-mail: felix_rocha_lvis@yahoo.com.br

3 Mestranda em Educação: Gestão de Ensino da Educação Básica (UFMA); Especialista em educação do Campo (UEMA). Orcid ID: http://orcid.org/0000-0003-2433-7233. E-mail: cileidinha83@hotmail.com
\end{abstract}


development, theoretical contributions related to color, Afro-Brazilian religiousness and Art teaching were used. The investigation concludes that the teaching of Art can be a curricular component for the understanding and the diffusion of the religiosity of African and Afro-Brazilian matrices in the school spaces.

Keywords: Curriculum. Chromatic study. Baião de Princesa.

EL BAÑO DE PRINCESAS DE LA CASA FANTI-ASHANTI: un estudio cromático en la enseñanza de Arte a la luz de la Ley N 10.639 / 03

\section{RESUMEN}

El presente artículo trata sobre la cromática en el ritual afro-maranhense "Baião de Princesas", en la Casa Fanti-Ashanti en la ciudad de São Luís. El estudio parte de la Ley de $N^{\circ} 10.639$ / 03 que hace obligatorio la enseñanza de la Historia y Cultura AfroBrasil y Africana en el currículo de las instituciones escolares. En la perspectiva de la enseñanza de arte, específicamente en el lenguaje Artes Visuales, se describió la simbología de los colores usados en las vestimentas de los vodunsis y de los ornamentos del salón, el cual, sucede el ritual religioso afro-maranhense. Para el desarrollo textual, se utilizaron aportes teóricos relacionados a colores, religiosidades afrobrasileñas y enseñanza de Arte. La investigación concluye que la enseñanza de Arte puede ser un componente curricular para la comprensión y la difusión de la religiosidad de matrices africana y afro-brasileña en los espacios escolares.

Palabras clave: Currículo. Estudio Cromático. Baião de Princesa.

\section{INTRODUÇÃO}

No dia 09 de janeiro de 2003, o Brasil aprova a primeira lei que torna obrigatório nos currículos das escolas públicas e privadas o ensino da História e Cultura Afro-Brasileira: a Lei de No 10.639/03. Neste sentido, a partir dessa data, a referida lei aponta para que as escolas possam inserir em seus currículos uma história afro-brasileira e africana, rompendo ou se diminuindo uma história eurocêntrica que ao longo dos tenros anos ficaram veiculadas como uma história de supremacia em relação à historia de outras civilizações, dentre elas, a africana.

Conforme o parágrafo $1^{\circ}$, artigo $1^{\circ}$, da Lei $n^{\circ}$ 10.639/03:

O conteúdo programático a que se refere o caput deste artigo incluirá o estudo da História da África e dos Africanos, a luta dos negros no Brasil, a cultura negra brasileira e o negro na formação da sociedade nacional, resgatando a contribuição do povo negro nas áreas social, econômica e política pertinentes à História do Brasil (BRASIL, 2015, p.1). 
Como vemos, a Lei $n^{\circ}$ 10.639/03 contempla a perspectiva de um currículo para e com a população negra ou afro-brasileira. Dessa forma, tem-se uma proposição de um currículo formal e real. O primeiro, entendido como aquele "estabelecido pelo sistema educacional, expresso em normas curriculares, desde seus objetivos até os conteúdos das áreas ou disciplinas de estudo" (LIBÂNEO; OLIVEIRA, 2003, p.56) e o segundo, "é aquele que é materializado em sala de aula pelos docentes e discentes à luz de uma contextualização histórico-social" (BORGES; ROCHA, 2014).

Acrescentamos, que apesar do currículo formal partir de um conjunto de prescrições oriundas das diretrizes curriculares, produzidas em âmbito nacional, nas secretarias e na própria escola, não é suficiente se não houver a sua materialização por meio de um currículo real. Sobre isso, Borges \& Rocha $(2014, s / p)$ descrevem:

O currículo real é a transposição pragmática do currículo formal, é a interpretação que professores e alunos constroem juntos, no exercício cotidiano, sejam conceituais, materiais ou na interação entre professor e alunos. São as sínteses construídas por professores e alunos, a partir dos elementos do currículo formal e das experiências pessoais de cada um.

Conforme Silva (2005), a construção e a materialização de um currículo envolve uma correlação de forças (poder), haja vista que nas relações humanas, sobretudo no modo de produção capitalista, os grupos em posições hegemônicas buscam assegurar seus domínios ou forças (poder) sobre os grupos que, ao seu modo, buscam se contrapor aos primeiros.

Na teoria curricular existem as teorias críticas e pós-críticas que têm em comum a negação de uma centralidade de poder de um grupo sobre outro. Para as teorias críticas "é através da formação da consciência que o currículo contribui para reproduzir a estrutura da sociedade capitalista" (SILVA, 2005, p. 148). E para as teorias pós-críticas, estas enfatizam que "o currículo não pode ser compreendido sem uma análise das relações de poder nas quais ele está envolvido" (SILVA, 2005, p. 149). Assim, ambas as teorias reconhecem que nas relações sociais incidem à variável saber ou 
conhecimento envolvido no poder de um grupo dominante. Nesta situação, originaram-se vários estudos voltados para as questões de raça, etnia, gênero, sexualidade e religiosidade de populações que, por muito tempo ficaram à margem da visibilidade dos conhecimentos no currículo formal das instituições de ensino.

Do exposto, a exigência ou a obrigatoriedade do ensino da História e Cultura Afro-Brasileira nas instituições escolarizadas da educação brasileira constitui uma conquista histórica dos movimentos sociais negros, que ao longo dos tempos reivindicavam as suas inserções nas relações sociorraciais brasileiras. Dessa forma, consideramos que o sistema escolar brasileiro precisa ensinar muitos legados deixados pela população africana e afro-brasileira para a formação social brasileira. À guisa de exemplo, têm-se as manifestações religiosas, que ainda nos dias atuais, são vistas como demoníacas à luz de uma religiosidade cristã e branca.

Em terras brasileiras as religiões de matriz africana deixaram uma multiplicidade de manifestações de cultos, que variando em cada estado, têm-se um tipo de religiosidade. No Rio de Janeiro existe a Umbanda; na Bahia, o Candoblé; em Pernambuco, o Xangô; no Pará, o Babaçuê; e no Maranhão, o Tambor de Mina (FERRETI, 1995).

E por consideramos que a Lei $n^{0} 10.639 / 03$ veio atender um currículo formal e real para e com a população afro-brasileira, o presente artigo trata sobre o culto religioso de matriz afro-maranhense denominado de Baião de Princesas da Casa Fanti-Ashanti, na cidade de São Luís, Estado do Maranhão, sobre o uso das cores das paramentações ${ }^{4}$ (indumentárias). Assim, defendemos que esse tipo de manifestação religiosa deve ser ensinado no currículo escolar, haja vista que poderá permitir uma visão, não preconceituosa a respeito não só do referido culto religioso em tela, como também de outros cultos de matriz africana ou afro-brasileira.

\footnotetext{
${ }_{4}^{4}$ Termo utilizado nos rituais de cultos afro-brasileiros, tendo os significados de: vestimentas, ornamentações, maquiagens, pinturas, fantasias.... (FERRETI, 1996). Todavia, para a presente pesquisa tem-se o significado de vestimentas ou indumentárias.
} 
A pesquisa faz uma descrição ritualística, destacando a cromática do Baião de Princesas. Tal ritual é realizado na Casa Fanti Ashanti no dia 13 de dezembro, aniversário do extinto Terreiro do Egito e festa de Santa Luzia. O estudo foi realizado no ano de 2012. Assim, o foco da investigação foi descrever o rito, indumentárias e a decoração da festa, assim como explicar a simbologia das cores.

O estudo constitui como uma pesquisa empírico-bibliográfica. A parte empírica foi a pesquisa in locus na Casa Fanti-Ashanti, especificamente no ritual Baião de Princesas, no ano de 2012; a parte bibliográfica são os aportes teóricos, os quais utilizamos: Ferreti (1996); Ferreti (1995); Nunes (1993); Rousseau (1980); Chagas (2010); Pedrosa (1996).

\section{O CURRículo NO ENSINO DE ARTE À LUZ DA LEI N $10.639 / 03$}

Segundo o parágrafo $2^{\circ}$, artigo $1^{\circ}$, da Lei $n^{\circ}$ 10.639/03: "Os conteúdos referentes à História e Cultura Afro-Brasileira serão ministrados no âmbito de todo o currículo escolar, em especial nas áreas de Educação Artística e de Literatura e História Brasileiras" (BRASIL, 2015, p. 1, grifos nossos). Assim, a área ou disciplina de Educação Artística, que foi modificada pelo Parecer $\mathrm{N}^{\circ} 22$, de 04 de outubro de 2005 para a nomenclatura de Arte, teve como principal justificativa: ser compreendida não mais como uma atividade, um mero "fazer por fazer", mas como uma forma de conhecimento". (BRASIL, 2005, p.2). Neste interin, a referida área passa a ser organizada, didaticamente, nas seguintes linguagens: Artes Visuais, Dança, Música e Teatro (BRASIL, 2005).

Do exposto, os conteúdos de Arte por meio de suas linguagens podem e devem ser trabalhados à luz da prescrição da Lei 10.639/03. Dentro dessa perspectiva, as manifestações de cultos africanos e afro-brasileiros contemplam aprendizagens referentes às quatro linguagens artísticas.

Segundo os Parâmetros Curriculares Nacionais de Arte, a linguagem artística Artes Visuais envolve a pintura, a escultura, o desenho, a gravura, a arquitetura, o artefato e o desenho industrial, a fotografia, o cinema, as artes gráficas, televisão, vídeo, computação e performance (BRASIL, 1997). Dessa 
forma, o conteúdo sobre cores e suas simbologias situa-se na pintura. À luz da Lei $n^{\circ}$ 10.639/03, o referido conteúdo pode ser trabalhado em diferentes assuntos da cultura afro-brasileira e africana. Os cultos religiosos são repletos de usos de cores, que vão desde as vestimentas às ornamentações dos salões das festas. Todavia, na maioria das vezes, as pessoas não sabem o significado e o sentido das cores nessas manifestações religiosas. Assim, consideramos que por meio do ensino da disciplina Arte, sobretudo na linguagem Artes Visuais, a escola pode possibilitar 0 conhecimento sistematizado e crítico a respeito dos cultos de matriz africana e/ou afrobrasileira.

\section{FÍSICA FISIOLOGIA E PSICOLOGIA DA COR}

A cor é uma sensação produzida através de impulsos nervosos com o auxilio da luminosidade. É uma ação da luz solar sobre a visão. A cor não possui uma essência material, ou seja, é uma sensação determinada por certos arranjos nervosos sob a ação da luz; é o efeito instigado pela atuação da luz sobre o órgão da visão. Segundo Pedrosa (1996, p. 17):

A cor não tem existência material: é apenas sensação produzida por certas organizações nervosas sob a ação da luz - mais precisamente, é a sensação provocada pela ação da luz sobre o órgão da visão. Seu aparecimento está condicionado, portanto, à existência de dois elementos: a luz (objeto físico, agindo como estímulo) e o olho (aparelho receptor, funcionando como decifrador de fluxo luminoso, decompondo-o ou alterando-o através da função seletora da retina).

Vale ressaltar que a cor está condicionada à luz para a sua existência. Ela não é um objeto físico e tem por finalidade agir e estimular o órgão da visão. O olho tem a função receptora de absorver a luminosidade, decompondo-a ou alterando-a através da função seletora da retina. As sensações cromáticas estão divididas em dois grupos respectivamente: o grupo das cores-luz, que pode ser chamada luz colorida, caracterizando-se como um feixe de luz visível a olho nu, possuindo em sua estrutura a luz branca. O outro grupo é da cor-pigmento, que é um fenômeno físico da 
absorção parcial ou total das radiações luminosas, que são substâncias coloridas que possuem um poder seletor sobre as radiações luminosas que os atingem (PEDROSA, 1996).

Conforme Chagas (2010, p.9)

\begin{abstract}
As cores da realidade existem no espaço que nos envolve, sendo que sua posição e relação com a luz influenciam a percepção do observador. A cor de um objeto não é definida pelo seu pigmento, mas sim pela imagem que o cérebro apreende e interpreta, porque a essência da cor se expressa através da reconstrução mental da realidade.
\end{abstract}

A cor em sua forma total se compõe como energia física, esta é captada por meio da fisiologia humana e é interpretada pelo cérebro, tendo uma relação bem estreita com a psicologia e percepção humana.

No domínio da física os elementos que constituem a realidade visível produzem ou refletem cores, expressas através de radiação eletromagnética. No ambiente da fisiologia, os olhos captam os estímulos visuais de radiação eletromagnética e registram-no através de receptores próprios da retina, os fotorreceptores. Cada receptor visual é sensível a um determinado ponto do espectro visual; os fotorreceptores subdividem-se em cones (que interpretam a luz) e bastonetes (que percepcionam a realidade sem informação cromática) (CHAGAS 2010).

Os estímulos visuais captados pelos olhos são direcionados até o córtex cerebral (através de nervos ópticos) sob a forma de impulsos elétricos. No que diz respeito à psicologia, a imagem da realidade é formulada e percebida no cérebro a partir de toda informação recebida e analisada. Portanto, um ato mais cerebral do que visual e implica uma relação entre a fisiologia e psicologia (NUNES, 2000).

Podemos levar em consideração que na percepção da realidade, a cor é responsável em definir a textura, brilho das formas, volumes e sombras, consequentemente, o espaço e tempo também se apresentam. Cada experiência cromática depende da intensidade da luz, da forma como esta é refletida e das cores envolventes, mas, apesar de ser o resultado de 
diferentes comprimentos de onda que estimulam o cérebro, a cor existe apenas mentalmente (CHAGAS, 2010).

A cor só se torna real com a presença de um observador, que utiliza a sua impressão fisiológica, da luz e da matéria que constitui o espaço. Em termos gerais cada indivíduo pode ter uma percepção cromática diferente; no entanto, cada indivíduo pode alcançar a mesma cor de distintas formas em função das situações e das cores envolvidas.

\section{UM BREVE HISTÓRICO DA COR}

Falar sobre a história e origem da cor não é tarefa fácil para pesquisadores e estudiosos da área, pois a mesma possui um duplo desenvolvimento. Se por um lado é necessário definir o universo cromático de uma determinada sociedade (cores de referência, códigos cromáticos, simbolismo), por outro é preciso analisar as transformações e inovação da cor (material, aplicação e léxico) ao longo do tempo, associadas a diferentes realidades artísticas, culturais e religiosas. (CHAGAS, 2010).

Apesar de ser impossível estabelecer uma história global da cor é fundamental e importante conhecer alguns períodos, pesquisadores e estudiosos que se tornaram grande destaque ao longo dos séculos a respeito do domínio da cor.

Conforme La Pastina (2016), dada uma estreita relação entre cor e luz, uma abordagem histórica sobre a cor relaciona-se incontrolavelmente com as questões da luz. Quando a cor era utilizada na Antiguidade, assumia majoritariamente um caráter simbólico, misterioso e mágico, acreditando-se no seu poder curativo. Por outro lado, a luz sempre se associou a superstições e mitos. O homem primitivo tinha um imenso respeito e veneração e, a relação entre o homem e a luz, ganhou inclusive conteúdo através da religião.

Na Grécia Antiga a cor e a luz foram objetos de estudos entre filósofos. Estes foram os pioneiros na investigação da cor que buscou compreender o fenômeno cromático e na arquitetura clássica grega, que constituiu o 
reconhecimento da policromia como meio de expressão tridimensional para altear as construções edificadas (POSSEBON, 2015).

Na Roma antiga, no século I a.C., ficou definida a Teoria Cromática por Plínio, onde as cores vermelho-vivo, a Ametista e a Conchífera eram consideradas as cores principais. Em meados do século II d.C., surge o interesse em fazer experiências subjetivas anunciando a subjetividade dos enfoques artísticos e teóricos do Alto-medieval. (POSSEBON, 2015).

Os Gregos também foram os percussores nas pesquisas sobre a luz, destacando grandes estudiosos que segundo Chagas (2010, p. 17):

\begin{abstract}
Também da Antiguidade, no domínio da investigação da luz, destacam-se estudiosos como Demócrito, Epicuro, Leucipo, Platão, Empédocles, Aristóteles, Euclides e Ptolomeu. Os três primeiros defendiam que a luz derivava dos objetos e era composto por partículas que formavam as imagens, sendo estas últimas responsáveis pela visão. Para Platão e Empédocles a luz provinha dos olhos, sendo as partículas suas componentes direcionadas aos objetos a partir da visão. Mais tarde Platão contrariou a ideia que colocava a luz e a cor como elementos provenientes da vista, defendendo que a cor existia no espírito de cada um, pelo fato de sua apreensão ser diferente de pessoa para pessoa. Para Aristóteles, a luz constituía uma energia imaterial característica dor ar e estimulado pelo fogo sendo considerado um dos elementos fundamentais para a transmissão das cores. Autor da mais antiga teoria de cor conhecido, Aristóteles acreditava que as cores pertenciam aos objetos e que a mistura do vermelho, verde, azul, amarelo, branco e preto dava lugar a todas as tonalidades existentes.
\end{abstract}

Outro fato de grande relevância ocorreu na Idade Média, por volta do século II, onde a heráldica 5 surgiu como a principal forma de organizar as cores, criada pela Cultura Ocidental tendo como a principal função o modo simbólico; os brasões militares foram os principais objetos definidores das cores emblemáticas.

No período medieval a luz passou a ser considerada pelos estudiosos como sendo de duas formas, a fonte de iluminação (lux) e o meio que permite a percepção luminosa e colorida (lúmen). No Renascimento a teoria de que a cor dependia da luz obteve grande destaque. Esta fase foi

\footnotetext{
5 Refere-se simultaneamente à ciência e à arte de descrever os brasões de armas ou escudos.
}

Revista Exitus, Santarém/PA, Vol. 9, № 4, p. 95 - 120, Out/Dez 2019. 
impulsionada pelo estudo da cor e, pintores e celebridades da Renascença tiveram fortes interesses em compreender o fenômeno da cor (POSSEBON, 2015).

Nomes como Leon Batista Alberti e Leonardo da Vinci destacaram-se como personalidades interessadas na compreensão do fenômeno da cor. Alberti associou as cores aos quatro elementos, definido o vermelho (fogo), o azul (ar), o verde (água) e o cinza (terra) como as cores principais. Leonardo da Vinci desenvolveu o conceito chiaroscuro (claro-escuro), um método de pintura que recorre ao contraste de luz e sombra para a representação dos objetos (CHAGAS, 2010).

Outros estudiosos destacaram-se na pesquisa no campo da cor e da luz. Como exemplos de pesquisadores, destacamos: Descartes, Newton e Goethe. Descartes em sua pesquisa descobriu que a luz é uma identidade ondulatória, todavia dois estudiosos que se sobressaíram foram Isaac Newton e Johann Wolfgang von Goethe, estes geraram discussão sobre a temática da luz e da cor, ocasionando grandes estudos sobre estes fenômenos. (FABRIN; BALISCEl; MENDES, 2017).

Goethe desmistificou a afirmativa de que a cor é o resultado de um produto da luz, mas é a forma em que se percepciona. Defendeu que o estudo da cor pode se dá através de experiências fisiológicas e da psicologia humana sem que utilizem os recursos ópticos. É correto afirmar que a teoria de Goethe era mais humanista, pois estava agregada ao fenômeno da visão e às emoções que as cores despertam. (POSSEBON, 2015).

Segundo Chagas (2010), foi no início do século XIX que o estudo cromático se tornou mais complexo devido a dicotomia entre cor expressa pela luz e cor lida através dos pigmentos. Também neste período, com o avanço da industrialização, as cores passaram a ser produzidas industrialmente e com grande recurso da química avançada havendo com isso um significativo aumento da produção de paletas cromáticas. Em 1839 , Michael Eugéne Chevreul estudou pela primeira vez (de uma forma exaustiva) a mistura óptica das cores através do contraste simultâneo, 
defendendo o caráter universal deste fenômeno pelo fato dos princípios cromáticos poderem ser igualmente aplicados em todas as situações.

Segundo a obra de Owen Jones, intitulada A Gramática do Ornamento escrita em 1856, a cor é abordada como sendo um fato primordial para as várias culturas e povos do mundo. No estudo de James Clerck, a visão da cor derivava da percepção dos diferentes comprimentos de onda e de partícula eletromagnética. O cientista Albert Einstein afirmou em 1905 que a luz podia existir em forma de onda e de partícula, manifestada em quanta. (FABRIN; BALISCEl; MENDES, 2017).

Outro fato de grande relevância foi o surgimento de várias interpretações e afirmações das teorias cromáticas de Goethe e de muitas reinterpretações de várias teorias da psicologia moderna. Segundo Chagas (2010, p. 19):

\footnotetext{
No início do século XX as teorias cromáticas de Goethe foram reinterpretadas pelos teóricos da Gestalt (psicologia da forma) e por alguns artistas modernos da Bauhaus como Paul Klee, Wassily Kandinsky, Josef Albers e Johannes Itten. Na sequência dos estudos realizados por Chevreul, Albers publicou (1963) a obra Interactian of Colors, desenvolvendo um estudo cromático baseado na cor aparente que percepcionamos e na relação desta com as outras cores. Em 1973 foi editado o livro The Arte Of Color no qual Itten analisou diferentes aproximações à cor no domínio da arte - uma mais subjetiva e emotiva outra mais objetiva e relacionada com os princípios cromáticos.
}

No período moderno, o estudo do conhecimento da área da arte e ciência se desenvolveu ativamente, com isso surgiram novas pesquisas e especialização no estudo da cor. Atualmente persiste uma oposição entre cor como objeto da ciência pura e cor no âmbito subjetivo da percepção e da cultura. Visto que a cor participa na interação das pessoas com a matéria, a percepção cromática e o conhecimento da cor resultam em parte da relação entre materialidade envolvente e o conhecimento humano. (LA PASTINA, 2016).

As cores sempre fizeram e fazem parte das atividades do cotidiano do homem. Mesmo para os povos com desenvolvimento tecnológico inferior, pode-se encontrar $o$ grande fascínio e influência da cor em uma 
determinada sociedade ou um grupo social. Os homens primitivos utilizavam a cor para a produção de suas pinturas rupestres e os indígenas que a utilizam para seus rituais religiosos.

\begin{abstract}
Para atividades da caça, da guerra, atividades religiosas e simbólicas, o homem se paramenta de cores, seja para assustar, agradar, ou apenas como prazer estético. As cores fazem parte do cotidiano dos homens desde priscas eras e mesmo entre os povos mais desenvolvidos tecnologicamente ela é elemento fundamental na sociedade, seja colorindo casas e habitações, ou tomando forma nos afrescos e pinturas em tela ou escultura em madeira e outros materiais. As cores estão presentes em todas as atividades humanas, que procura imitar a natureza que é sempre colorida, seja nos reinos animal, vegetal ou mineral. Tudo é cor, tudo são matizes, tudo vibra no contato com a luz, criando um mundo de formas e texturas que impressionam e comovem o olhar humano (KIUNDUNDULU; ADOLFO, 2012).
\end{abstract}

Segundo Kiundundulu e Adolfo, (2005, p. 1), na história da arte humana vê-se que, adornos corporais, aparatos de guerra, instrumentos musicais, utensílios domésticos, seja qual fosse a finalidade ou a forma do instrumento, o homem destacava e destaca essas formas com as cores mais variadas e luminosas; utilizando-se de materiais que tinha à mão - seja folhas e troncos macerados, barro de várias procedências, carvão de madeiras e outros matérias - na intenção de dar-Ihes um colorido e uma expressividade maior.

\title{
COR E SIMBOLOGIA NO ESTUDO CROMÁTICO DO BAIÃO DE PRINCESAS
}

O Baião de Princesas é um ritual festivo ligado a Cura (linha da água doce), realizado na Casa Fanti Ashanti no dia 13 de dezembro dia de Santa Luzia, protetora da visão. Neste evento, as entidades homenageadas são femininas (princesas, rainhas, caboclas). O Baião é dançado na Casa Fanti Ashanti apenas por mulheres incorporadas com entidades espirituais femininas (senhoras da Mina, Caboclas e princesas da Mina e da cura) (FERRETI, 1996).

O Baião de Princesas da Casa Fanti Ashanti, enquanto ritual de matriz africana, pode evidenciar as cores em sua totalidade. Elas fazem parte do ritual e estão presentes nas roupas, adereços e decoração da casa. Assim, como nas demais religiões, seja através das comidas, nos enfeites da casa,

Revista Exitus, Santarém/PA, Vol. 9, № 4, p. 95 - 120, Out/Dez 2019. 
ou nas pinturas rituais dos iniciados. Enfim, o jogo em torno das cores é carregado de um significado extremo, é central na representação ritualística.

Presenciou-se no dia 13 de dezembro de 2012 a festa do Baião de Princesas, especialmente as cores presentes no ritual. Buscamos dessa maneira, destacar as cores nas indumentárias das dançantes (Vodunsis) e nas bandeiras hasteadas no teto do barracão. O foco do estudo foi correlacionar o significado das cores no ritual, com alguns teóricos.

Ao entrar no barracão, o que chamou mais atenção foi o teto hasteado de bandeiras de cor azul e branco. É neste salão principal que ocorrem os rituais e se pode fazer analogia a essas cores como simbolizando o céu.

Vejamos, a figura abaixo que mostra as bandeiras das cores azul e branca no teto do salão do Baião de Princesas:

Figura 1: Ornamentação do teto do salão do Baião de Princesas

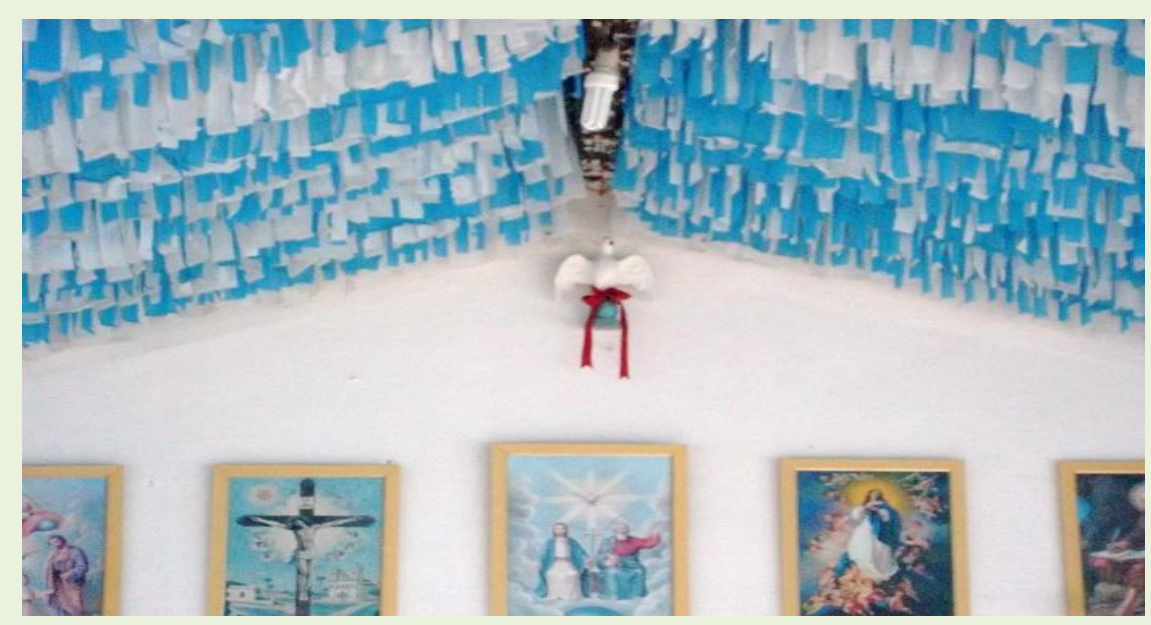

Fonte: Pesquisa empírica.

A cor branca tem uma gama de significados, é uma cor que representa a pureza, leveza e paz. O branco simboliza proteção, alegria, conforto, o amor de Deus, e contribui na paz espiritual.

O branco revela pureza, sinceridade e verdade; repele energias negativas e eleva as vibrações espirituais. Equilibra a aura e facilita o contato com os guias espirituais, promovendo o equilíbrio interior, a sensação de 
proteção. Também pode ser usado como coringa, para todos os propósitos, associando-se com eficiência com qualquer cor. A cor branca remete a paz, sinceridade, pureza, verdade, inocência, calma. A luz branca traz todas as cores, ilumina e transforma. Representa o amor divino, estimula a humildade e a sensação de limpeza e claridade. Ótima para qualquer ambiente, contudo se o local for totalmente branco pode se resultar em sensação de tédio e monotonia. O branco sugere pureza e o infinito. Evoca o frio e a umidade, sobretudo, quando combinado com o azul.

A cor azul assim como a branca tem grandes significados, ela é uma das cores que pode ser observada diariamente no cotidiano, representa a cor do planeta Terra.

O azul é uma cor que representa a realeza, a aristocracia, simboliza o frescor, estabilidade, lealdade, confiança, sabedoria, inteligência, fé, verdade, eternidade, a tranquilidade do ser humano, por isso ela está associada ao céu. É a cor do espírito e do pensamento. Simboliza a lealdade, a fidelidade, a personalidade e sutileza. Simboliza também o ideal e o sonho. Produz ternura, afetuosidade, paz de espírito e segurança. Simboliza devoção, fé, aspirações elevadas, sinceridade, confiança e tranquilidade. O azul transmite e favorece a compreensão. É a cor do bem estar e do raciocínio lógico. É a única que tem poder de desintegrar energias negativas, favorecendo a paciência, a amabilidade e a serenidade (ROUSSEAU, 1980, p. 37).

Segundo Rousseau (1980, p. 38),

a cor azul celeste tem sido necessariamente associada, no espírito dos homens, a uma ideia de elevação de leveza, de ar, de esferas inacessíveis, ao menos pelo corpo (...). Esse azul é o ar, o céu e também a luz que, do mesmo modo que o ar envolve os seres vivos, os domina, provocando neles, as emanações de vida.

A cor azul está presente no cotidiano, ela é facilmente identificada nas pigmentações dos tecidos e até mesmo na cor do céu. Segundo Nunes (2000, p. 57-58 ) A visão do planeta Terra, tanto de fora como de dentro é azul, hoje, sem nenhuma dificuldade, essa visão belíssima, pode ser desfrutada quase diariamente, pelas fotos das naves espaciais. A partir dessa peculiaridade de detalhes, não será difícil uma avaliação da importância da cor azul em tudo que possa se referir ao mundo. 
O homem e a cor possuem uma relação estreita, pois ela surge através do mecanismo da visão, baseado no aparelho óptico, em conexão com o cérebro. Também o componente psicológico está incluso, pois ele possui uma afinidade entre a cor e vivência e cor e memória. A percepção cromática é um fenômeno individual e subjetivo e possui uma relação significativa entre o homem e a cor (LA PASTINA, 2016).

Segundo Chagas (2010), a cor é um elemento importante na definição da identidade do homem, havendo cores associadas do passado. Quando o homem recorre a uma determinada memória está também recorrendo à determinada cores. Se a memória é tão importante na construção da identidade humana, então a cor é um elemento fundamental na definição da mesma. As imagens que o homem tem de cada lugar existe em função das cores e são possíveis pelo recurso da memória.

Podemos observar que as saias de estilo longo possuíam quatro cores diferentes: azul claro, verde, laranja e rosa e uma única possuía um estilo de saia adamascado6, além dos Banté que tinham as cores branca, rosa e amarelo, ambas com desenhos estilizados com borboleta e flor.

Percebemos no ritual do Baião de Princesas que as blusas das Vodunsis seguiam uma cor padrão (branco), como também está presente em muitos outros rituais religiosos de matriz africana, em contraste com as saias que se apresentam com variação cromática.

Vejamos, a figura 2, que mostra a nossa descrição:

6 Esse tecido possui desenhos brilhantes e opacos podem ser de seda, raiom, linho ou algodão. Muito usado nas roupas femininas. 
Figura 2: Vodunsis iniciando o ritual no Baião de Princesas

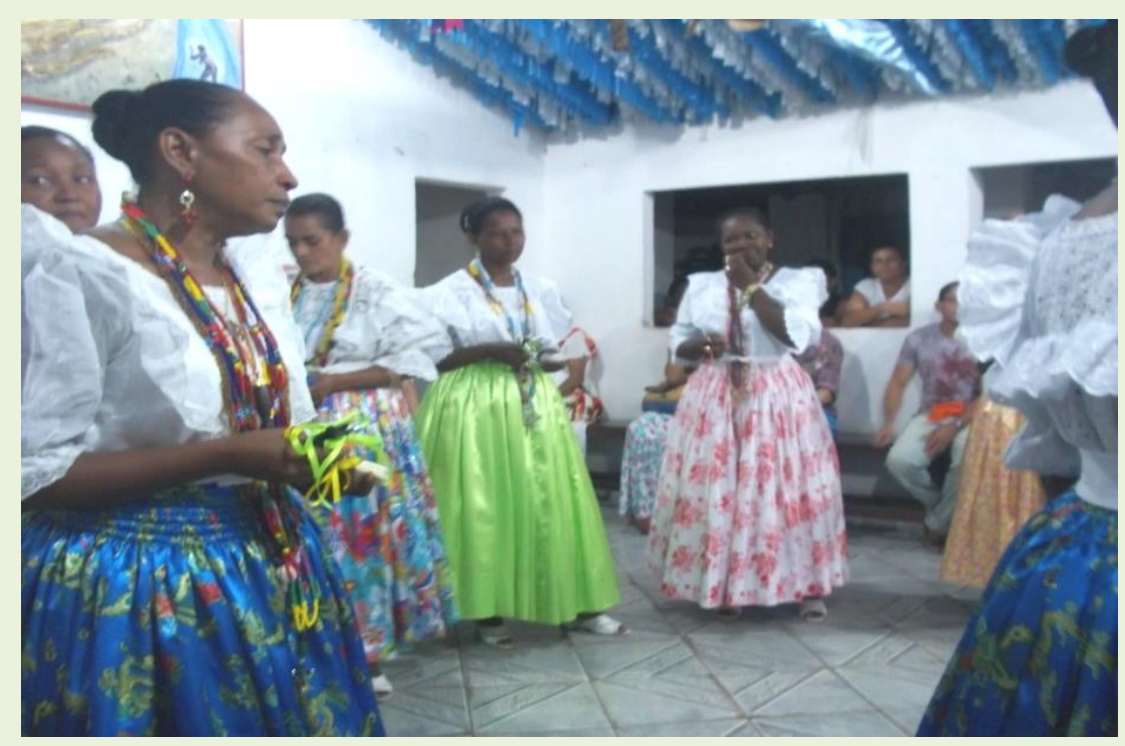

Fonte: pesquisa empírica.

Chagas (2010) afirma que a cor sempre foi utilizada como um símbolo e elemento conceitual, sendo o conceito variável consoante à estrutura de cada sociedade. As componentes simbólicas das cores fazem parte da vida humana. Muitos dos rituais celebrados recorrem simbolicamente a determinadas cores, das quais o preto, o branco e o vermelho são os mais predominantes.

A simbologia da cor nasce na Idade Média, por volta do século XII, momento em que surge a heráldica. Esse sistema de cor era considerado como absoluto, desconhecendo as outras variações de cor. A heráldica possuía em sua estrutura seis cores designadas a seguir: branco, amarelo, vermelho, preto, azul e verde, mais tarde foi acrescentado a sétima cor, o cinzento violáceo. Neste sentido:

\begin{abstract}
A simbologia da cor remonta ao período medieval, quando no século XII surgiu a heráldica, as cores deste sistema eram claramente simbólico, sobretudo por serem tratadas como absolutas, ignorandose as variações. Na heráldica a gama cromática é reduzida a seis cores originais: branco (prata), amarelo (ouro), vermelho (goles), preto (sable), azul (azur) e verde (sinople); as quais se acrescentou uma sétima cor, o cinzento violáceo (púrpura) (CHAGAS, 2010, p. 39).
\end{abstract}

O homem se preocupou em classificar, ou seja, conceituar as cores e para isso foi necessário utilizar o processo subjetivo, atribuindo conceito, 
nomes. Vale ressaltar que a cor em sua totalidade possui diferentes significâncias e classificações que são traduzidas por nomenclaturas para cada cultura. A cor sempre esteve no cotidiano da humanidade, sua simbologia está associada a uma gama de significados que se perpetua ao longo do tempo e sempre esteve ligada ao desenvolvimento sociocultural da sociedade. Dessa forma:

Em todas as épocas, as sociedades organizadas sempre tiveram seus códigos completos, ou certos elementos de uma simbologia das cores, atribuindo-lhes frequentemente caráter mágico. A variedade de significados de cada cor ao longo dos tempos está intimamente ligada ao nível de desenvolvimento social e cultural das sociedades que os criam (PEDROSA, 1996, p. 99).

A fusão das três etnias na formação brasileira tornou o gosto pela cor, mestiço, onde os padrões dos povos dominantes (europeus) se entrelaçaram aos dos negros e indígenas, tornando-se em estilo próprio e original.

Segundo Pedrosa (1996), do confronto dos três elementos étnicos fundamentais da população brasileira surgiu um gosto estético que cada vez mais se distancia do gosto de cada grupo original. No tocante a cor, os padrões dominantes do gosto europeu deixaram influências pelos negros e indígenas, o que gerou um gosto caracteristicamente mestiço diferenciado dos demais povos residindo neste o núcleo de sua originalidade.

Durante o ritual do Baião de Princesas foi possível percebermos, no momento em que as Vodunsis incorporadas com suas encantadas entram no salão, que ambas estavam paramentadas com suas respectivas indumentárias e suas cores. Cada uma das entidades possuía um estilo de cor próprio. Percebemos a presença das cores branca, azul, rosa, amarelo, verde e vermelho.

Verificamos que o uso de saias estampadas predominavam nos motivos florais. Segundo a simbologia cromática, cada cor tem seu significado. A cor laranja presente na saía da Vodunsi, para Nunes (2000), é uma cor energizadora. Para Pedrosa (1996), do ponto de vista místico, o laranja é fruto do ouro-celeste, na direção da revelação do amor divino. 
A cor laranja é quente, sendo a mistura exata entre o amarelo e o vermelho. É uma cor ativa que significa movimento e espontaneidade. Cor do sucesso, da agilidade mental, e da prosperidade. Para Rousseau (1980, p. 138), simboliza encorajamento, estímulo, robustez, atração, gentileza, cordialidade, tolerância e prosperidade. A cor Laranja é também a cor da comunicação, do calor afetivo, do equilíbrio, da segurança, da confiança. É uma cor das pessoas que creem que tudo é possível, estimulando o otimismo, generosidade, entusiasmo.

Na página seguinte, mostramos a cor laranja na saia de uma Vodunsi.

Figura 3: saia de cor laranja de uma Vodunsi

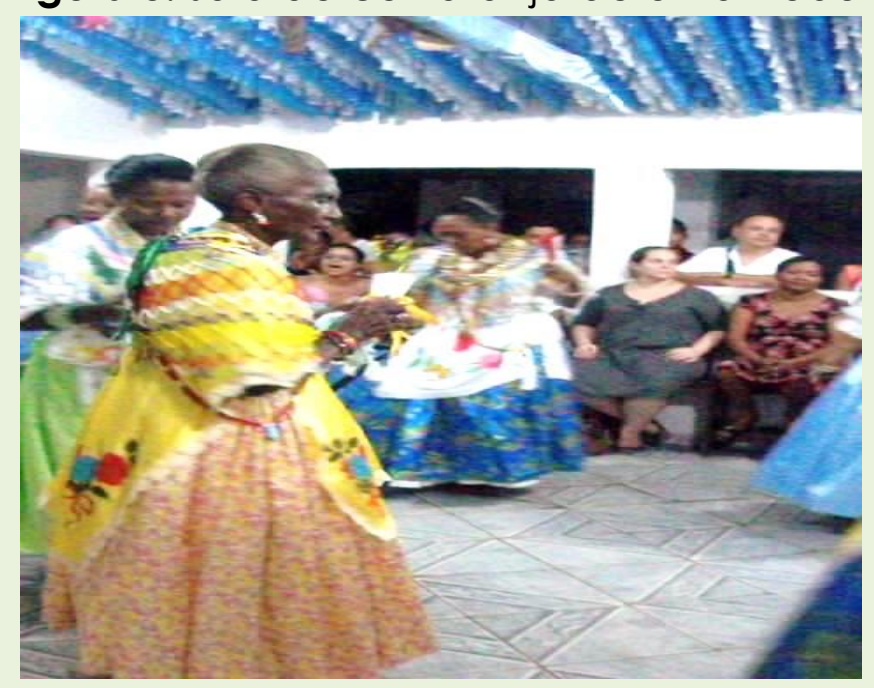

A partir das observações do ritual, constatamos que cada Vodunsi possuía um Banté (um tecido de cetim ou ceda que vêm pintados ou bordados com flores ou borboletas) que se apresentam nas seguintes cores: amarelo, branco, rosa e azul.

Segundo Rousseau (1980, p. 123-124):

O rosa é como o amor e a sabedoria. O rosa tem um significado feminino como a flor que ostenta a sua cor. Rosa é o ideal feminino, sempre impulsionou profundamente a humanidade. Suas proporções harmoniosas, suas cores delicadas e frescas, que lembram a pele de crianças e das moças ou um belo céu da aurora, seu perfume penetrante, o tecido delicado do qual são feitas as suas pétalas, tudo isso indica essa flor para se tornar um símbolo da beleza e, mais especificamente - com a graça aliando-se a beleza- da beleza feminina idealizada. A rosa, portanto é naturalmente um emblema 
da mulher ideal, da mulher celeste, ela é a imagem da virgem Maria, rainha do jardim de Deus.

Na figura abaixo, mostramos a cor rosa no Banté. Vejamos:

Figura 4: Banté da cor rosa em roupa de uma Vodunsi

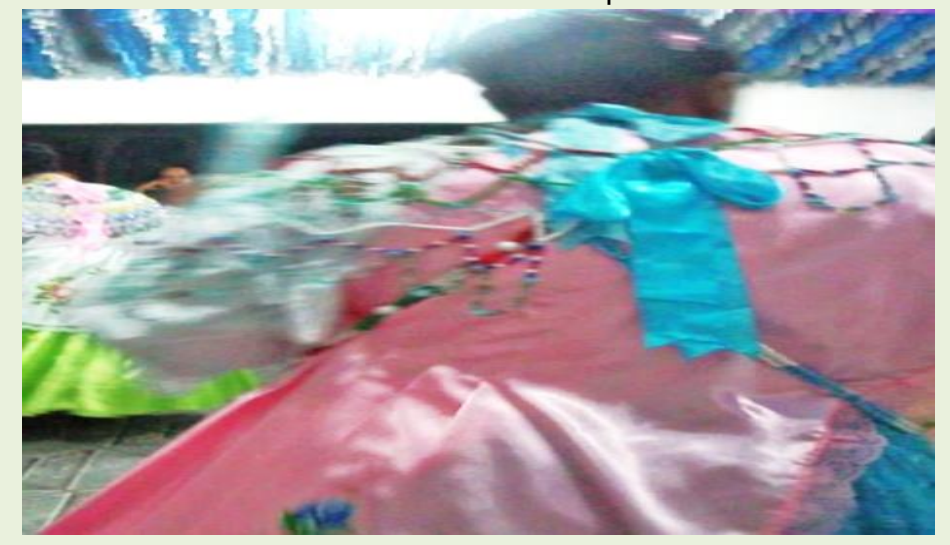

Fonte: pesquisa empírica.

Analisando a cor rosa, percebemos que ela está presente em quase todo o ritual, desde a decoração dos altares, do Banté das filhas de santo, das cortinas. Nas saias das princesas é uma cor viva, graciosa e bastante feminina.

Verificamos, também a cor rosa no toalha do altar. Eis, a figura:

Figura 5: Toalha de cor rosa no altar do salão Baião de Princesas

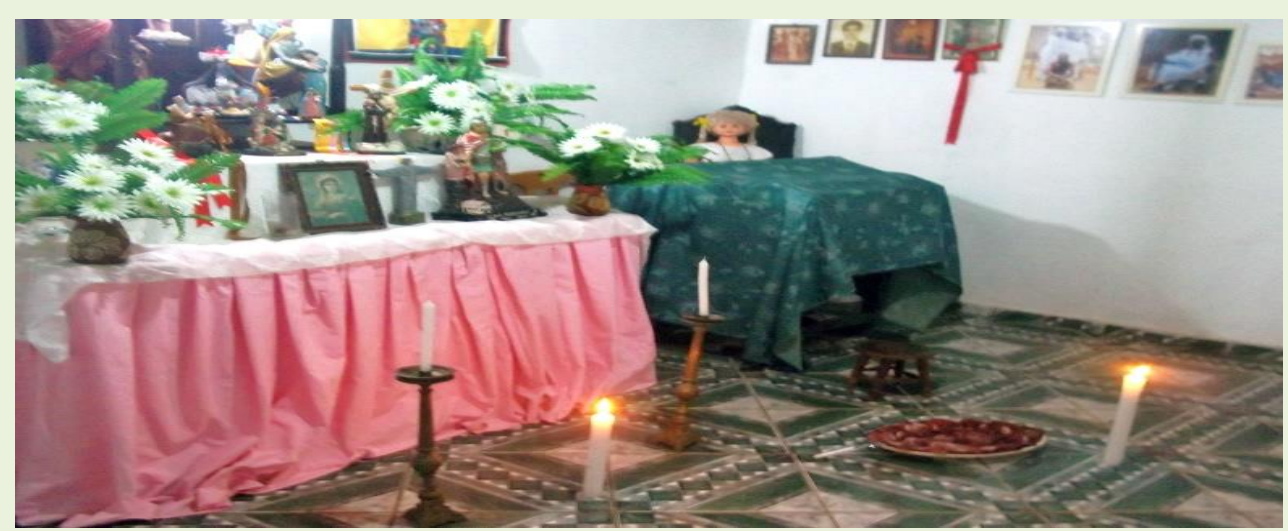

Fonte: pesquisa empírica.

A cor amarela nas religiões de matriz africana é representado pelo orixá Oxun. No candomblé e no Tambor de Mina como Vodun Azem, segundo Ferreira (1997, p.100): 
Dos iorubas é feminina por excelência [...] é essencialmente as divindades das mulheres e preside as funções fisiológicas femininas: a menstruação, a gravidez, o parto, a gestação, o nascimento, a fecundidade e a riqueza. Oxun ama as crianças como ninguém, Oxum é a mulher menina que gosta de brincar com bonecas, nada recusa e nunca se enfurece, é dona do ouro é bastante calma, é a rainha da sociedade das mulheres.

Assim como a cor rosa, a cor amarela também representa essencialmente a feminilidade.

Abaixo, mostramos a cor amarela na vestimenta de uma Vodunsi.

Figura 6: Cor amarela na vestimenta de uma Vodunsi

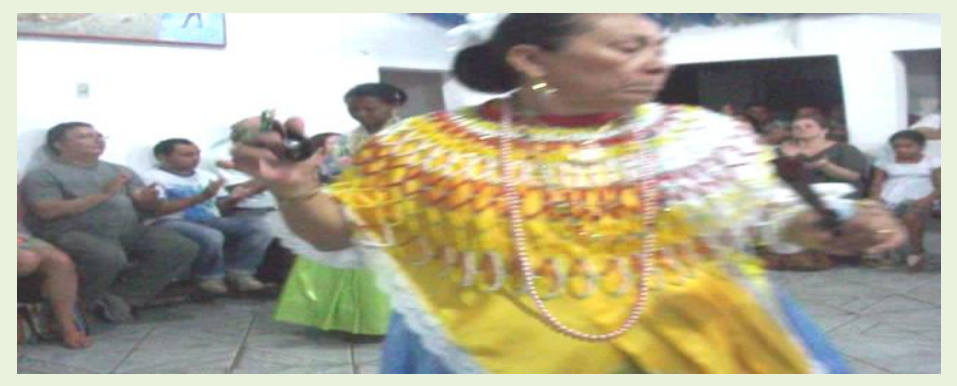

Fonte: pesquisa empírica.

Outra cor presente no ritual é o verde. Segundo Rousseau (1980), o verde é a personificação da própria Natureza, não como força atuante, mas como força atuada. O verde é o aspecto feminino da Natureza: a Mãe e a nutriz. Concebe o Amor, princípio de todos os seres. Seu culto, portanto, reúne todas as divindades femininas.

Na figura da página seguinte, mostramos a cor verde na saia de uma Vodunsi. 
Figura 7: Cor verde na saia de uma Vodunsi

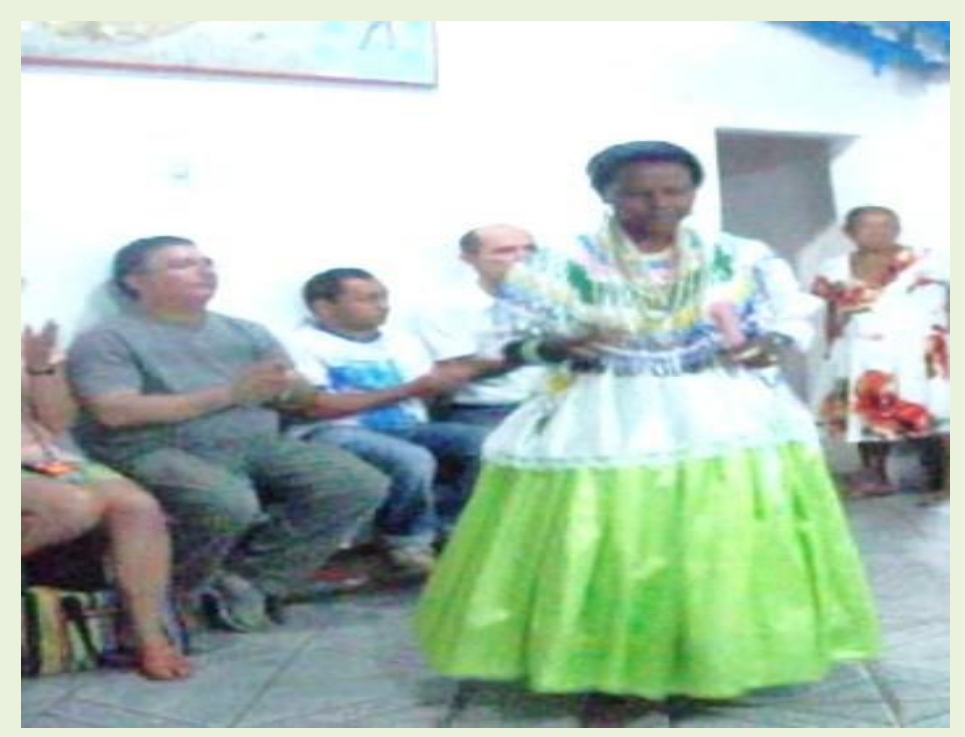

Fonte: pesquisa empírica.

A cor branca é outra cor no ritual do baião de Princesas, além de estar nas blusas de todas as Vodunsis está presente em alguns Banté. Segundo Rousseau (1980), a cor branca, ao exprimir a unidade e a divindade, exprime ao mesmo tempo a totalidade dos conhecimentos, a ciência última, em uma palavra, a verdade e a sabedoria. Se o branco é a cor da ciência divina e do conhecimento integral, traduz ao mesmo tempo ideias de consciência moral, de pureza, de integridade.

Na figura seguinte, mostra a cor branca na bata de uma Vodunsi:

Figura 8: cor branca na bata de uma Vodunsi

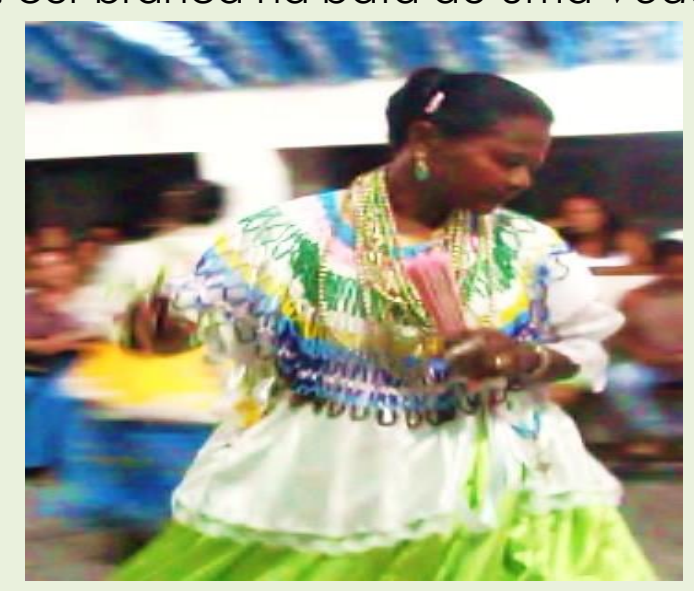

Fonte: pesquisa empírica. 
Outra cor observada durante o ritual, foi a cor vermelha. Essa cor estava em uma fita que servia para amarrar a manta de contas de uma encantada.

Segundo Zylberglejd (2017, p.39)

O simbolismo do vermelho está marcado por duas vivências elementares: o vermelho é o fogo e o vermelho é o sangue. Tanto o fogo quanto o sangue possuem um significado atrelado à nossa existência, em todas as culturas e todos os tempos. Além disso, está é a cor de todas as paixões - as boas e as más, do amor ao ódio. A explicação física para este significado é que ao ficarmos constrangidos, apaixonados, irritados, com vergonha ou excitado, o sangue sobe à cabeça, deixando nosso rosto vermelho.

A seguir, mostramos uma figura com a cor vermelha numa fita sobre a manta de contas.

Figura 9: a cor vermelha numa fita sobre a manta de contas

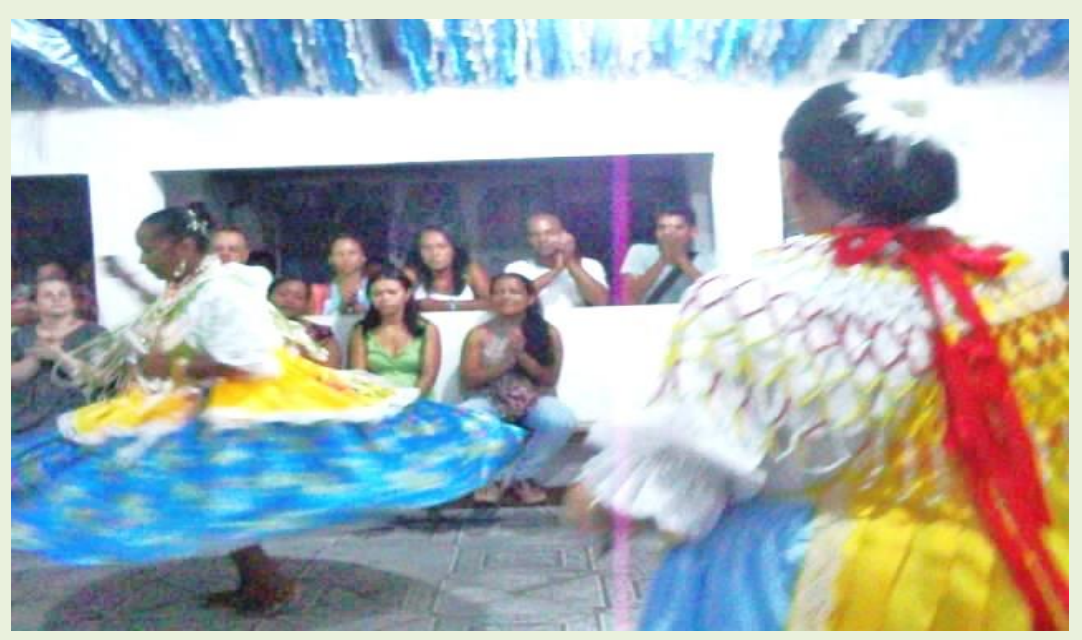

Fonte: pesquisa empírica.

\section{CONSIDERAÇÕES FINAIS}

Estudar o universo afro-religioso brasileiro não é uma tarefa tão simples, muito menos em descrever de maneira aleatória rituais de um terreiro de religião afro-brasileira. Almejamos fazer uma descrição ritualística de um estudo cromático do Baião de Princesas na perspectiva de servir para ser difundido e ensinado na disciplina de Arte, especificamente na linguagem de Artes Visuais. 
Conforme o Parecer $n^{\circ}$ 03, de 10 de março de 2004, no item Ações Educativas no Combate ao Racismo e a discriminações, aponta:

O ensino de História e Cultura Afro-Brasileira e Africana se fará por diferentes meios, em atividades curriculares ou não, em que: - se explicitem, busquem compreender e interpretar, na perspectiva de quem o formule, diferentes formas de expressão e de organização de raciocínios e pensamentos de raiz da cultura africana; promovam-se oportunidades de diálogo em que se conheçam, se ponham em comunicação diferentes sistemas simbólicos e estruturas conceituais, bem como se busquem formas de convivência respeitosa, além da construção de projeto de sociedade em que todos se sintam encorajados a expor, defender sua especificidade étnico-racial e a buscar garantias para que todos o façam; - sejam incentivadas atividades em que pessoas - estudantes, professores, servidores, integrantes da comunidade externa aos estabelecimentos de ensino - de diferentes culturas interatuem e se interpretem reciprocamente, respeitando os valores, visões de mundo, raciocínios e pensamentos de cada um (BRASIL, 2016, p.11, grifos nossos).

Do exposto, compreendemos que os cultos religiosos, de modo geral, são sistemas simbólicos que cada cultura abstrai. Neste sentido, o Baião de Princesas, que é um ritual de matriz afro-maranhense, carrega um conjunto de simbologias, tanto nos paramentos das Vodunsis, quanto no salão da referida festa.

Consideramos que não só ritual de Baião de Princesas, como também outros rituais de matrizes africana e afro-brasileira podem ser inseridos no contexto de um currículo formal e real nas escolas. Dessa forma, caracterizase um currículo voltado para o respeito e a valorização da cultura negra.

É preciso que a educação brasileira, cada vez mais, avance no combate ao preconceito e da discriminação racial da população negra por meio de um currículo que possa desenvolver posicionamentos críticos e respeitosos em relação às diversas manifestações culturais, não só dos negros, como também de outras matrizes étnico-raciais. Assim, presenciamos a cada momento uma expressiva quantidade de visualidade no percurso histórico da humanidade, logo, necessitamos de uma educação para saber compreender e distinguir emoções, sensações, ideias e atributos. Para um desenvolvimento de uma educação voltada para percepção visual é necessário um estudo das visualidades, que devem esta interligados a 
projetos educacionais. Dessa forma, a Lei $n^{\circ}$ 12.287/10377, destaca que, "tal aprendizagem pode favorecer compreensões mais amplas para que 0 aluno desenvolva sua sensibilidade, afetividade e seus conceitos e se posicione criticamente" (BRASIL, 2010, p.45).

\section{REFERÊNCIAS}

BRASIL. Lei No 10.639/03. Brasília, 2015. Disponível em:< http://www.planalto.gov.br/CCivil_03/leis/2003/L10.639.htm>. Acesso em 15 fev. 2019.

BRASIL. Secretaria de Educação Fundamental. Parâmetros curriculares nacionais: Arte / Secretaria de Educação Fundamental. - Brasília: MEC/SEF, 1997. Disponível em: <http://portal.mec.gov.br/seb/arquivos/pdf/livro06.pdf>. Acesso em 20 abr 2017.

BRASIL. Parecer $n^{\circ}$ 22/2005 de 4/10/2005. Solicitação de retificação do termo que designa a área de conhecimento "Educação Artística" pela designação: "Arte, com base na formação específica plena em uma das linguagens: Artes Visuais, Dança, Música e Teatro". Ministério da Educação, Brasília, 2015. Disponível em: < http://portal.mec.gov.br/conselho-nacionalde-educacao/atos-normativos--sumulas-pareceres-e-resolucoes?id=12740>. Acesso em: 30 abr 2018.

BRASIL. Parecer $\mathbf{n}^{\circ}$ 003, de 10 de março de 2004. Brasília, 2016. . Disponível em:< http://portal.mec.gov.br/dmdocuments/cnecp_003.pdf>. Acesso em 14 set 2017.

BRASIL. Lei $n^{\circ}$ 12.287, de 13 de julho de 2010. Câmara dos Deputados, Brasília, 2018. Disponível em: http://www.planalto.gov.br/ccivil_03/_ato20072010/2010/lei/l12287.ht.

BORGES, F. P.; ROCHA, A. S. Currículo Formal e Funcional: a Formação Coletiva No Estado do Paraná. Secretaria Estadual de Educação do Paraná. 2014. Disponível em: < http://www.diaadiaeducacao.pr.gov.br/portals/cadernospde/pdebusca/pr oducoes_pde/2014/2014_uem_gestao_artigo_flavio_pascoal_borges.pdf>. Acesso em 28 fev. 2019

CHAGAS, D. Á. Cor e conservação: As intervenções Cromáticas no Terreiro do Paço. Dissertação (Mestrado). - Universidade Técnica de Lisboa, Faculdade de Arquitetura. 2010. Disponível

\footnotetext{
7 Lei que Altera a Lei no 9.394, de 20 de dezembro de 1996, que estabelece as diretrizes e bases da educação nacional, no tocante ao ensino da arte. (BRASIL, 2018).
}

Revista Exitus, Santarém/PA, Vol. 9, № 4, p. 95 - 120, Out/Dez 2019. 
em:<https://www.repository.utl.pt/handle/10400.5/2625>. Acesso em: 23 jan. 2019.

FABRIN, M. E. C.; BALISCEI, J. P.; MENDES, S. M. da C. Quando o corpo veste cores: cultura visual e duas versões de viva la vida. Revista Educação e Linguagens, Campo Mourão, v. 6, n. 11, jul./dez. 2017. Disponível em: < http://www.fecilcam.br/revista/index.php/educacaoelinguagens/article/vie wFile/1473/1049>. Acesso em 20 fev 2019.

FERREIRA, E. M. Tambor de Mina em Conserva. Casa Fanti Ashanti 1997, São LuÍS - MA.

FERRETI. S. F. Repensando o sincretismo. São Paulo: EDUSP, 1995.

FERRETI. M. Desceu na Guma: O caboclo do Tambor de Mina no processo de mudança de um terreiro de São Luís: a Casa Fanti-Ashanti. São Luís: EDUFMA, 1996.

KIUNDUNDULU, T. K.; ADOLFO, S. P. de N. O Simbolismo das Cores no Candomblé de Congo-Angola. Disponível em:

<http://www.inzotumbansi.org>. Acesso em: 23/04/2013.

LA PASTINA, C. C. Pesquisas Cromáticas. Revista Cadernos de Pesquisa:

Pensamento Educacional, v. 1, n.29, 2016. Disponível em: <

https://seer.utp.br/index.php/a/article/view/447/414>. Acesso em 20 fev. 2019.

LIBÂANO, J. C.; OLIVEIRA, J. F. de; TOCHI, M. S. Educação escolar: políticas, estrutura e organização. São Paulo: Cortez, 2003.

NUNES, R. Cromoterapia Aplicada. 5.ed. - Brasília 2000.

PEDROSA, I. Da cor à cor inexistente. Brasília: Léo Christiano Editorial, 1996.

POSSEBO, E. A TEORIA DAS CORES DE GOETHE. Sociedade Antroposófica no Brasil, 2015. Disponível:

<http://www.sab.org.br/portal/images/Artigos/artes/teoria-das-cores-degoethe/teoriadascores-enniopossebon.pdf>. Acesso em 20 fev 2019.

ROUSSEAU, R-L. A linguagem das Cores. São Paulo: Editora pensamento, 1980.

SILVA, T. T. da. Documentos de Identidade: uma introdução às teorias do currículo. Belo Horizonte: Autêntica, 2005.

ZYLBERGLEJD, R. A influência das cores nas decisões dos consumidores. Universidade Federal do Rio de Janeiro. Escola Politécnica. 2017. Disponível 
em: <http://monografias.poli.ufrj.br/monografias/monopoli10023496.pdf>. Acesso em 15 fev 2019.

Recebido em: 28 de fevereiro de 2019 Aprovado em: 26 de agosto de 2019 